\author{
돼지의 교배조합 - 도체등급 및 출하일령이 도체특성에 미치는 영향 \\ 김계웅·김석은 \\ 공주대학교 동물자원학과
}

\title{
Effect of Mating System, Carcass Grade and Age at Marketing on Carcass Characteristics of Pigs
}

\author{
Gye-Woong Kim and Seok-Eun Kim \\ Department of Animal Resources Science, Kongju National University
}

\begin{abstract}
This study was carried out to investigate the carcass characteristics of crossbred pigs according to mating system, carcass grade and age at marketing. A total of 656 pigs of 128 gilts and 528 barrows were collected and analyzed at public slaughter house. Differences between LY and LYD crossbred on marbling score and water holding capacity were significantly $(\mathrm{p}<0.05)$ found. The influences of LY and LYD crossbred on carcass weight, backfat thickness, meat colour, carcass grade and age at marketing were not significantly showed. The carcass weight of $\mathrm{D}$ carcass grade was significantly $(\mathrm{p}<0.05)$ heavier than that of the other grade. The backfat thickness was significantly $(\mathrm{p}<0.05)$ appeared gradually in accordance with the increase of carcass grade. There was significantly difference among the carcass grades on water holding capacity $(\mathrm{p}<0.05)$. The differences among the carcass grades on the meat colour, marbling score and age at marketing were not found significantly. The carcass weight of high age group at marketing was significantly heavier than that of the low age group $(p<0.05)$. The backfat thickness of the group of high age at marketing was significantly thicker than that of the group of low age $(\mathrm{p}<0.05)$. There were significant differences among age group at marketing in marbling score, carcass grade, and water holding capacity, respectively $(\mathrm{p}<0.05)$. The carcass weight was positively correlated with the backfat thickness but negatively correlated with the carcass grade. The correlation between the backfat and carcass grade was significantly negative. The meat colour was negatively correlated with water holding capacity.
\end{abstract}

(Key words : Mating system, Carcass grade, Age at marketing, Carcass characteristics)

$$
\text { I. 서 론 }
$$

우리나라 육류자원 중에서 돼지고기는 가장 큰 소 비 비중을 차지하고 있다. 1 인당 돼지고기 소비량은 2000년, 2006년과 2007년에 각각 $16.5 \mathrm{~kg}, 18.1 \mathrm{~kg}$ 과 $19.2 \mathrm{~kg}$ 으로 해를 거듭할수록 증가 추세에 있다(농림 수산식품부, 2008).

돼지고기는 등지방 두께를 얇게 하고, 체지방 축적 이 낮으며, 산육성이 높고, 사료효율이 양호한 살코기 형 육량 위주로 생산해 왔으나 (Larzul 등, 1997; Choi, 2004; Choi 등, 2005), 최근 생활여건의 향상으로 육류 소비는 증가하면서 맛과 영양은 물론 건강적인 측면 을 고려한 우수한 품질의 기능성 식육을 선호하고 있 다(송 등, 2002). 고급 돼지고기는 육색이 약간 선홍 색을 띠며 육질은 탄력성과 조직감이 있어야할 뿐만 아니라 신선하고 위생적인 조건을 갖추어야 한다(Lee 등, 1996; Choi 등, 2005). 이와 같은 살코기형 돼지고 기일수록 육즙손실이 많으며, 지방이 견고하지 못하
고, 다즙성이나 풍미가 나쁜 것으로 보고되고 있다 (Wood 등, 1988; Choi 등, 2005; Hah 등, 2005). 그리고 $\mathrm{pH}$ 가 낮을수록 보수력도 낮아지는 것으로 알려져 있 다(Joo 등, 1999). 이와 같은 여러 육질변화 요인을 분 석하여 양질의 돼지고기를 생산 또는 관리하는 일은 대단히 중요하다.

돼지의 증체나 육질에는 품종, 교배조합, 성별, 출하 일령, 사양관리 등에 따라 많은 영향을 미치는 것으로 조사되고 있는데, Choi 등 (2000)은 돼지의 출하일령과 성별에 따라 도체와 육질에 영향을 미치며, Park 등 (2005)은 도체중과 등지방 두께도 도체등급이나 도체 특성에 영향을 준다고 보고하였다. 돼지의 육질이나 맛과 같은 형질은 유전적으로 상당한 변이가 존재하 는 것으로 보고되고 있다(Carmeron, 1990; Hovenier 등, 1994). 그리고 도체등급 결정에서는 도체중, 근육 내 지방량, 육의 연도, 육색 등은 중요한 기준이 된다 고 보고한 바도 있다(Boggs and Merkel, 1984; Park 등, 2007). 또한 육색은 신선도와 관련하여 소비자의

Corresponding author : Seok Eun Kim, Dept. of Animal Resources Science, Kongju National University \#1 Daehoeri, Yesan, Chungnam 340-702, Korea

Tel: 041-330-1240, Fax: 041-330-1249, E-mail: sekim@kongju.ac.kr 
구매의욕에 많은 영향을 미친다고 하였다 (Zhu and Brewer, 1998).

본 연구는 비육돈 656 두를 대상으로 도체등급 판정 을 받아 품종별, 도체등급별 및 출하일령별로 구분하 여 도체와 육질의 특성을 규명하여 양돈농가의 경쟁 력 확보를 위한 고급 돼지고기 생산에 필요한 기초적 자료를 얻고자 수행하였다.

\section{ㅍ. 재료 및 방법}

\section{1. 공시재료}

공시재료는 전산기록을 관리하고 있는 중부지방 10 개 농장에서 평균 176 일령 사육한 암퇘지 128 두와 거 세돼지 528 두를 가지고 도체등급을 판정받은 총 656 두를 대상으로 하였다 (Table 1).

\section{2. 조사항목 및 조사방법}

도체등급판정을 실시하고 있는 $\mathrm{H}$ 도축장에서 도축 후 돼지도체등급판정기준(탕박)에 의하여 5 등급으로 판정한 자료를 이용하여 도체중은 이분도체의 온도체 의 무게를 측정하였고, 등지방 두께는 $5^{\circ} \mathrm{C}$ 이하로 예 냉된 도체 등(背)의 최후 늑골 부위를 직각으로 절단 하여 지방의 두께를 측정하였다. 육색도는 우리나라 육질기준표 (No. 1 6)를 사용하여 조견표에 따라 엷 은 육색은 1 점에서 가장 짙은 것은 6점을 부여하여 수치화로 측정하였으며, 근내 지방도는 최장근 단면의 근내지방 침착정도를 근내지방 조견표 (No. 1 5)를 이용하여 마블링이 약하게 침착된 육단면은 1 점에서 많은 상태는 5점까지 부여하여 산술적으로 점수화하 였다.

보수력은 Honikel (1987)의 방법을 약간 변형하여 지 방을 제거한 등심근 시료 $50 \mathrm{~g}$ 을 $70^{\circ} \mathrm{C}$ 에서 30 분간 가 열한 다음 냉각하여 $1,000 \mathrm{rpm}$ 에서 10 분간 원심분리후 전체 처음 무게에서 수분으로 삼출된 무게를 측정하 여 [(총 시료중량 - 유리수분 중량) / 총시료중량 $\times 100$ ] 산출하였다. 교배조합 품종과 출하일령은 출하된 10 개 대상농장의 기록과 설문을 통하여 조사하였고, 도체등 급은 도체육질판정 기준 (농림부, 2007)에 따라 등급사 에 의해 판정되었으며, 등급 점수는 $\mathrm{A}$ 등급은 4점에 서 $\mathrm{D}$ 등급은 1점으로 도체등급별로 수치화하여 표시
하였다.

\section{3. 통계처리 및 분석}

자료의 통계처리는 SAS (Statistical Analysis System, 1997)을 이용하여 평균과 표준편차를 구하였고, 처리 평균치간의 차이는 t-test와 Duncan의 multiple range test로 $5 \%$ 수준에서 유의성을 검정하였으며, 도체형질 측정치 간에는 Pearson의 상관계수를 추정하여 분석하 였다.

\section{III. 결과 및 고찰}

\section{1. 교배조합별 도체특성}

교배조합별 도체특성의 평균과 표준편차는 Table 2 에서 보는 바와 같다. 도체중은 $\mathrm{LY}$ 종과 $\mathrm{LYD}$ 종에서 각각 $87.0 \mathrm{~kg}$ 과 $89.0 \mathrm{~kg}$ 으로 3원교잡 $\mathrm{LYD}$ 종에서 다소 무거운 경향을 보였으나 유의차는 없었다. 이러한 도 체중은 Lee 등 (1996)과 Choi 등 (2005)이 LYD종에서 유의하게 $(\mathrm{p}<0.05)$ 가장 무거웠다는 결과와 대체적으로 일치하였는데, 이러한 3 원교잡종에서의 무거운 결과는 잡종강세에 기인한 것으로 사료된다.

등지방 두께는 $\mathrm{LY}$ 종과 $\mathrm{LYD}$ 종에서 각각 $22.7 \mathrm{~mm}$ 와 $24.9 \mathrm{~mm}$ 로 2 원교잡종보다는 3 원교잡종에서 두꺼운 경 향을 보였다. 이와 같은 결과는 Lee 등 (1996)이 Duroc 순종에서 $3.40 \mathrm{~cm}$ 로 가장 두꺼웠으며, 그 다음은 $\mathrm{LYD}$ (YLD)종, $\mathrm{LY}(\mathrm{YL})$ 종순으로 얇았다고 보고한 결과와 는 다소 차이가 있었으나, 순종 $\mathrm{LL}$ 종, $\mathrm{YY}$ 종 그리고 $\mathrm{DD}$ 종 보다는 잡종 $\mathrm{LY}$ 종, $\mathrm{LYD}$ 종순으로 두껍다는 $\mathrm{Kim}$ 등 (2006)의 결과와 일치하였다.

육색도는 2 품종간에는 통계적 유의차는 없었으나, 표준색 3.0 보다는 모두 짙은 것으로 나타났으며, LY 종 3.5 보다 LYD 종에서 유의차는 없지만 3.7로 약간 더 짙은 경향을 보였다. 이러한 육색도의 결과는 Lee 등 (1996)과 Choi 등 (2000)이 유의한 차이가 없다는 보 고와도 대체적으로 유사하였다.

근내 지방도는 $\mathrm{LY}$ 종과 $\mathrm{LYD}$ 종에서 각각 1.5 와 2.1로 교배품종 간에 유의성 있는 $(\mathrm{p}<0.05)$ 차이를 보 였다. 이러한 결과는 교잡종에서 근내 지방도가 높게 나타나고, Yorkshire와 Landrace와 같은 순종일수록 유 의하게 낮게 나타난다는 Lee 등(1996)의 보고와 서로

Table 1. Distribution of gilt and barrow pig used in this experiment

\begin{tabular}{|c|c|c|c|c|c|c|c|c|c|}
\hline \multirow{2}{*}{ Classification } & \multicolumn{3}{|c|}{ Gilt } & \multicolumn{3}{|c|}{ Barrow } & \multicolumn{3}{|c|}{ Overall total } \\
\hline & YL(LY) & YLD(LYD) & sub-total & YL(LY) & YLD(LYD) & sub-total & YL(LY) & YLD(LYD) & total \\
\hline Heads & 22 & 106 & 128 & 378 & 150 & 528 & 400 & 256 & 656 \\
\hline$\%$ & 3.4 & 16.2 & 19.6 & 57.6 & 22.9 & 80.5 & 61.0 & 39.0 & 100 \\
\hline
\end{tabular}


Table 2. Carcass characteristics of pig according to mating system

\begin{tabular}{lrc}
\hline \multicolumn{1}{c}{ Traits } & LY(YL) & LYD(YLD) \\
\hline \hline Carcass weight $(\mathrm{kg})$ & $87.0 \pm 8.0$ & $89.0 \pm 8.6$ \\
Backfat thickness (mm) & $22.7 \pm 3.6$ & $24.9 \pm 5.1$ \\
Meat colour (1-6) & $3.5 \pm 0.7$ & $3.7 \pm 0.7$ \\
Marbling score (1-5) & $1.5 \pm 0.5^{\mathrm{b}}$ & $2.1 \pm 1.0^{\mathrm{a}}$ \\
Carcass grade (1-4) & $3.0 \pm 1.0$ & $2.7 \pm 1.1$ \\
Water holding capacity (\%) & $58.0 \pm 33.9^{\mathrm{a}}$ & $44.5 \pm 33.4^{\mathrm{b}}$ \\
Age at marketing (days) & $177.8 \pm 4.8$ & $177.6 \pm 9.6$ \\
\hline a,b $:$ Means with different & superscripts are & significantly \\
different (p<0.05). & &
\end{tabular}

유사하였다.

도체등급은 교배조합 품종간 유의한 차이는 없었으 나, 3품종 교배보다 2품종간 교배종인 $\mathrm{LY}$ 종에서 평 균 3등급으로 다소 양호한 경향을 보였다.

보수력은 $\mathrm{LY}$ 종에서 $58.0 \%$, 그리고 $\mathrm{LYD}$ 종에서 $44.5 \%$ 로 교배조합 간에는 통계적으로 유의한 차이 $(\mathrm{p}<0.05)$ 를 나타냈다. 이와 같은 유의한 결과는 Choi 등(2005), Jin 등(2006) 및 Kim 등 (2006)이 교배조합간 에 보수력은 유의한 차이가 있다고 보고한 것과 대체 적으로 일치하였다.

출하일령은 $\mathrm{LY}$ 종과 $\mathrm{LYD}$ 종에서 교배조합간 유의 한 차이가 없이 각각 177.8 일과 177.6 일로 매우 비슷 한 경향을 보였다.

\section{2. 도체등급별 도체특성}

돼지의 도체등급별로 구분하여 도체형질을 분석한 평균과 표준편차의 결과는 Table 3 과 같다. 도체중은 도체등급 간에 통계적 유의차 $(\mathrm{p}<0.05)$ 가 인정되었다. $\mathrm{A}$ 등급 도체군에서는 $84.0 \mathrm{~kg}$ 으로 가장 가벼운 반면에 $\mathrm{D}$ 등급군에서는 $98.9 \mathrm{~kg}$ 으로 가장 무거운 도체중을 보 였는데, 상위 $\mathrm{A}, \mathrm{B}, \mathrm{C}$ 등급간에는 유의한 차이는 없이 등급이 높을수록 도체중이 가벼운 경향을 보였다. 이
러한 결과는 $\operatorname{Jin}$ 등 (2004)이 상위등급 간에는 유의성 은 없으나 낮은 등급과는 유의한 차이가 있었다고 보 고한 결과와 대체적으로 유사하였으나, 도체중이 무거 울수록 $\mathrm{A}, \mathrm{B}$ 등급 출현율이 높았다는 것과는 서로 다 른 결과를 보였는데, 이와 같은 결과는 공시돈의 체중 차이에 기인한 것으로 사료된다.

등지방 두께는 A 등급 돈군에서는 $21.2 \mathrm{~mm}$ 로 유의 하게 $(\mathrm{p}<0.05)$ 가장 얇았으나, D 등급군에서 $29.1 \mathrm{~mm}$ 로 가장 두꺼웠다. 따라서 도체등급이 떨어질수록 등 지방 두께는 두껍게 나타났다. 이러한 결과는 $\mathrm{Jin}$ 등 (2004)이 A 등급과 B 등급에서 각각 $21.0 \mathrm{~mm}$ 와 23.69 $\mathrm{mm}$ 로 보고한 내용과 거의 일치하였으나 하위등급에 서는 다소 차이가 있는 것으로 나타났다.

육색도에서는 $\mathrm{A}, \mathrm{B}, \mathrm{C}, \mathrm{D}$ 등급 순으로 등급이 낮을 수록 육색도가 짙은 경향을 보였으나, 등급간에는 통 계적으로 유의한 차이는 발견되지 않았다. 이와 같은 결과는 원 (1997)과 $\operatorname{Jin}$ 등 (2004)이 육색 $\left(\mathrm{L}^{*}\right.$ 값과 $\mathrm{b}^{*}$ 값)은 도체 등급간에 유의한 차이가 없었다는 보고와 대체적으로 일치하였다.

근내 지방도는 도체등급간에는 유의한 차이는 없었 으나 상위 등급일수록 낮고, 하위 등급일수록 높은 경 향을 보였는데, 이러한 결과는 Jin 등 (2004)이 교잡종 돼지에서 유의성은 인정되지 않지만 상위등급 $(\mathrm{A}$ 와 $\mathrm{B}$ 등급)에서는 기타 등급에 비하여 근지방 함량이 다소 높게 나타났다는 결과와 다소 상이하였다.

보수력에서는 도체 등급간에 통계적 유의차 $(\mathrm{p}<0.05)$ 가 인정되었다. $\mathrm{A}$ 등급과 $\mathrm{C}$ 등급에서 각각 $57.8 \%$ 와 $56.4 \%$ 로 비교적 높게 나타났으나, $\mathrm{B}$ 등급과 $\mathrm{D}$ 등급에 서는 비교적 낮게 나타났다.

출하일령은 도체 등급간에 유의한 차이는 없었으나 상위등급인 A 등급군에서 174.7 일이 걸렸으나, D 등 급군에서는 180.3 일이 소요된 것으로 보아 출하일령이 빠를수록 $\mathrm{A}$ 등급 출현율이 향상된 것으로 생각된다.

\section{3. 출하일령별 도체특성}

돼지의 출하일령에 따른 도체형질의 평균과 표준편 차는 Table 4에서 보는 바와 같다.

Table 3. Carcass characteristics by carcass grade of pig

\begin{tabular}{lrrrr}
\hline \multicolumn{1}{c}{ Traits } & A & B & C & D \\
\hline \hline Carcass weight (kg) & $84.0 \pm 3.8^{\mathrm{a}}$ & $85.5 \pm 7.7^{\mathrm{a}}$ & $89.3 \pm 8.2^{\mathrm{ab}}$ & $98.9 \pm 6.7^{\mathrm{b}}$ \\
Backfat thickness (mm) & $21.2 \pm 2.5^{\mathrm{a}}$ & $23.4 \pm 3.9^{\mathrm{a}}$ & $26.5 \pm 4.0^{\mathrm{a}}$ & $29.1 \pm 5.0^{\mathrm{b}}$ \\
Meat colour (1-6) & $3.4 \pm 0.7$ & $3.5 \pm 0.8$ & $3.5 \pm 0.8$ & $3.7 \pm 0.8$ \\
Marbling score (1-5) & $1.6 \pm 0.7$ & $1.6 \pm 0.8$ & $1.9 \pm 0.9$ & $2.1 \pm 1.1$ \\
Water holding capacity (\%) & $57.8 \pm 36.1^{\mathrm{a}}$ & $46.9 \pm 38.7^{\mathrm{b}}$ & $56.4 \pm 37.3^{\mathrm{a}}$ & $47.3 \pm 38.8^{\mathrm{b}}$ \\
Age at marketing (days) & $174.7 \pm 7.7$ & $176.1 \pm 8.4$ & $178.1 \pm 7.8$ & $180.3 \pm 7.9$ \\
\hline
\end{tabular}

${ }^{\mathrm{a}, \mathrm{b}}$ : Values with different superscript are significantly different $(\mathrm{p}<0.05)$. 
Table 4. Carcass characteristics by age at marketing in pigs

\begin{tabular}{lccccc}
\hline \multicolumn{1}{c}{ Traits } & $160 \sim 165$ & $166 \sim 170$ & $171 \sim 180$ & $181 \sim 185$ & $186 \sim 190$ \\
\hline \hline Carcass weight (kg) & $85.1 \pm 8.6^{\mathrm{c}}$ & $85.2 \pm 4.9^{\mathrm{c}}$ & $90.2 \pm 7.4^{\mathrm{b}}$ & $90.9 \pm 8.9^{\mathrm{b}}$ & $96.3 \pm 7.9^{\mathrm{a}}$ \\
Backfat thickness (mm) & $22.9 \pm 4.0^{\mathrm{b}}$ & $23.3 \pm 4.9^{\mathrm{b}}$ & $23.3 \pm 4.4^{\mathrm{b}}$ & $24.5 \pm 4.2^{\mathrm{b}}$ & $28.5 \pm 5.3^{\mathrm{a}}$ \\
Meat colour (1-6) & $3.7 \pm 0.8$ & $3.3 \pm 0.8$ & $3.6 \pm 0.8$ & $3.3 \pm 0.7$ & $3.8 \pm 0.8$ \\
Marbling score (1-5) & $1.7 \pm 0.8^{\mathrm{bc}}$ & $1.5 \pm 0.8^{\mathrm{c}}$ & $1.8 \pm 0.9^{\mathrm{b}}$ & $1.5 \pm 0.6^{\mathrm{c}}$ & $2.1 \pm 1.2^{\mathrm{a}}$ \\
Carcass grade (1-4) & $3.1 \pm 1.1^{\mathrm{a}}$ & $3.2 \pm 1.0^{\mathrm{a}}$ & $2.7 \pm 1.2^{\mathrm{ab}}$ & $2.9 \pm 1.1^{\mathrm{ab}}$ & $1.9 \pm 1.1^{\mathrm{b}}$ \\
Water holding capacity (\%) & $55.5 \pm 35.9^{\mathrm{ab}}$ & $59.0 \pm 38.1^{\mathrm{a}}$ & $52.8 \pm 36.9^{\mathrm{b}}$ & $59.5 \pm 37.8^{\mathrm{a}}$ & $32.4 \pm 14.3^{\mathrm{c}}$ \\
Carcass grade A at 1st (\%) & 46.0 & 53.5 & 41.6 & 43.2 & 12.4 \\
\hline ab,c $:$ Val & & & &
\end{tabular}

$\overline{\mathrm{a}, \mathrm{b}, \mathrm{c}}$ : Values with different superscript are significantly different $(\mathrm{p}<0.05)$.

도체중은 출하일령간에 통계적 유의차 $(\mathrm{p}<0.05)$ 가 인 정되었다. 186 190일령 돈군에서 $96.3 \mathrm{~kg}$ 으로 도체중이 가장 무거운 반면에, 출하일령이 빠른 개체군에서는 가장 가볍게 나타났다. 본 연구의 결과는 Choi 등 (2000)이 출하일령은 도체중에 유의적 차이는 미치지 않지만 160 일령보다 180 일령에서 무거운 경향을 보였 다는 결과와 서로 상이하지만 일령이 많을수록 높다 는 내용은 비슷하였다.

등지방 두께는 출하 186 190일령 돈군에서 28.5 $\mathrm{mm}$ 로서 가장 두꺼운 반면에, 출하일령이 짧을수록 등 지방 두께는 얇게 나타났다. 이러한 결과는 180 일령에 서 $28.6 \mathrm{~mm}$ 로 유의하게 두껍고, 출하일령이 가장 빠른 160 일령 군에서 $25.6 \mathrm{~mm}$ 로 얇았다는 Choi 등 (2000)의 보고와 일치하였다. 그리고 Lee와 Joo (1999)가 도체중 이 무거울수록 유의한 등지방 두께 차이가 있다고 보 고한 것과도 대체적으로 유사하였다.

육색은 출하일령 간에는 통계적으로 유의한 차이는 없었으나 출하일령이 가장 늦은 186 일령 이상 집단에 서 높은 경향치를 보였다. 이와 같은 결과는 Choi 등 (2000)과 Cho 등 (2007)이 육색은 출하일령 간에 유의 차는 없었으나 일령이 많을수록 높은 경향으로 보고 한 내용과 서로 비슷한 결과를 보였다.

근내 지방도는 출하일령 간에 통계적 유의차 $(\mathrm{p}<$ 0.05 )가 인정되었는데, 출하일령이 높은 186 190일령 돈군에서 2.1점으로 가장 높은 것으로 나타났다.
보수력에서는 출하일령 간에 유의한 차이 $(\mathrm{p}<0.05)$ 를 보였다. 출하 185 일령 이하 개체군에서 $52.8 \%$ 에서 $59.5 \%$ 까지 비교적 높은 반면에, 186 일령 이상 군에서 는 $32.4 \%$ 의 매우 낮은 보수력을 가지고 있었다. 이와 같이 출하일령이 빠른 개체군에서 보수력이 낮은 결 과는 Choi 등 (2000)이 출하일령이 높을수록 보수력이 유의하게 떨어진다는 보고와 대체적으로 일치하였다.

도체등급 1 차 판정 결과에서 출하일령별 $\mathrm{A}$ 등급 출 현율은 166 170일령군에서 $53.5 \%$ 로 가장 높게 나타난 반면에, 186 일령 이상의 출하일령 돈군에서는 $12.4 \%$ 로 매우 낮게 나타났는데, 일령이 많을수록 A 등급 도체판정 출현율이 낮은 것으로 조사되었다.

\section{4. 도체형질간의 상관관계}

돼지의 도체형질간의 상관계수를 추정한 결과는 Table 5와 같다. 도체중은 등지방 두께와 비교적 높은 정 $(+)$ 의 상관 $(\mathrm{r}=0.538)$ 이 있으나, 도체등급과는 부 $(-)$ 의 상관 $(\mathrm{r}=-0.654)$ 이 존재하였다. 이러한 결과는 Lee 와 Joo (1999)가 도체중과 등지방 두께 간에는 정의 상 관 $(\mathrm{r}=0.65)$ 으로 보고한 결과와 일치하였다.

등지방 두께와 도체등급 간에는 유의하게 $(\mathrm{p}<0.01)$ 부 $(-)$ 의 고도상관 $(\mathrm{r}=-0.643)$ 이 존재하여 등지방 두 께가 두꺼울수록 도체등급은 떨어지는 것으로 추정된 다. 또한 육색은 보수력과 고도의 수준으로 부(-)의

Table 5. Correlation coefficients between carcass characteristics of pigs

\begin{tabular}{lccccccc}
\hline \multicolumn{1}{c}{ Traits } & $\mathrm{X}_{1}$ & $\mathrm{X}_{2}$ & $\mathrm{X}_{3}$ & $\mathrm{X}_{4}$ & $\mathrm{X}_{5}$ & $\mathrm{X}_{6}$ & $\mathrm{X}_{7}$ \\
\hline \hline Carcass weight $\left(\mathrm{X}_{1}\right)$ & 1 & $0.538^{*}$ & 0.045 & 0.196 & $-0.654^{* *}$ & 0.052 & 0.343 \\
Backfat thickness $\left(\mathrm{X}_{2}\right)$ & & 1 & 0.044 & 0.211 & $-0.643^{* *}$ & 0.046 & 0.323 \\
Meat colour $\left(\mathrm{X}_{3}\right)$ & & & 1 & 0.193 & -0.109 & $-0.605^{* *}$ & 0.004 \\
Marbling score $\left(\mathrm{X}_{4}\right)$ & & & & & -0.229 & $0.470^{*}$ & 0.099 \\
Carcass grade $\left(\mathrm{X}_{5}\right)$ & & & & 1 & 0.088 & -0.123 \\
Water holding capacity $\left(\mathrm{X}_{6}\right)$ & & & & & & & -0.270 \\
Age at marketing $\left(\mathrm{X}_{7}\right)$ & & & & & & 1 \\
\hline
\end{tabular}

$*: \mathrm{p}<0.05, \quad * *: \mathrm{p}<0.01$. 
상관관계 $(\mathrm{r}=-0.605)$ 가 있었는데, 이는 육색도 (Hunter $\mathrm{a}^{*}$ : 적색)와 육즙손실 (drip loss) 간에는 부의 상관 $(\mathrm{r}=$ $-0.25)$ 이 존재한다는 Lee와 Joo (1999)의 결과 보다 비교적 높았다. 근내 지방도는 보수력과 정 $(+)$ 의 중등 상관 $(\mathrm{r}=0.470)$ 이 존재하였다. 그 밖의 형질 간에는 유의성 없이 매우 낮은 상관계수이거나 거의 없는 것 으로 나타났다.

이상의 결과로 보면, 2 품종간의 교배보다는 3 품종 간의 교배에서 도체중, 육색, 보수력 등에서는 우수하 였으며, 상위등급에서는 등지방두께, 보수력, 출하일령 등에서 다소 양호하였다. 그리고 출하일령이 빠를수록 등지방두께, 육색, 도체등급, 보수력, 1 차 $\mathrm{A}$ 등급 출현 율 등이 비교적 우수한 성적으로 나타났다.

\section{IV. 요 약}

본 연구는 도체 등급판정을 받은 비육돈 $\mathrm{LY}$ 및 $\mathrm{LYD}$ 교잡종 중 암퇘지 128 두와 거세돈 528 두, 총 656 두를 공시돈으로 교배조합, 도체등급 및 출하일령별 도체 및 육질특성을 조사하여 고급돈육생산에 필요한 기초적 자료를 얻고자 실시하였다.

교배조합별 도체특성의 변화에서 근내 지방도와 보 수력은 두 교배조합 간에 각각 통계적으로 유의한 차 이 $(\mathrm{p}<0.05)$ 를 보였으나, 도체중, 등지방 두께, 육색, 도 체등급 및 출하일령은 두 교배조합 간에 유의차가 나 타나지 않았다. 도체등급별 도체특성 분석에서 도체중 은 도체등급이 떨어질수록 유의하게 $(\mathrm{p}<0.05)$ 무거웠 다. 등지방 두께는 도체등급이 높을수록 유의하게 $(\mathrm{p}<$ $0.05)$ 얇은 성적을 나타났으나, 육색도에서는 도체등급 간에 통계적 유의차는 없었다. 보수력은 도체등급 간 에 유의한 차이 $(\mathrm{p}<0.05)$ 를 보인 반면에, 출하일령은 유의성 있는 차이는 나타나지 않았다. 출하일령별 도 체특성에서 도체중과 등지방 두께는 출하일령 간에 통계적으로 유의하게 $(\mathrm{p}<0.05)$ 일령이 많을수록 무겁게 나타났으나, 육색은 일령간에 유의한 차이를 보이지 않았다. 근내 지방도는 출하일령이 많을수록 유의하게 $(\mathrm{p}<0.05)$ 높았으나, 도체등급과 보수력에서는 출하일령 이 적을수록 유의하게 $(\mathrm{p}<0.05)$ 높게 나타났다. 그리고 $\mathrm{A}$ 등급 출현율은 출하일령이 높은 돈군보다 166 170 일령 돈군에서 $53.5 \%$ 로 가장 높게 나타났다. 도체형질 간의 상관계수 추정에서 도체중은 등지방 두께와 정 $(+)$ 의 중등 상관이었으나, 도체등급과는 부 $(-)$ 의 상 관이 존재하였으며, 등지방 두께와 도체등급 간에는 부 $(-)$ 상관, 육색과 보수력 간에는 고도의 부 $(-)$ 의 상관, 그리고 근내 지방도와 보수력은 정 $(+)$ 의 중등 상관이 각각 존재하였다.

\section{V. 인 용 문 헌}

1. Boggs, D. L. and Merkel, R. A. 1984. Live Animal
Carcass Evaluation and Selection Manual, Kendall/hunt Publishing Company, Dubuque, Iowa.

2. Carmeron, N. D. 1990. Genetic and phenotypic parameters for fatty acid composition of subcutaneous fat, meat quality, carcass composition and eating quality traits in pigs. Proc. 4th WCGALP 15:549.

3. Cho, S. H., Park, B. Y., Kim, J. H., Kim, M. J., Seong, P. N., Kim, Y. J., Kim, D. H. and Ahn, C. N. 2007. Carcass Yields and Meat Quality by Live Weight of Korean Native Black Pigs. J. Anim. Sci. \& Technol. 49: 523-530.

4. Choi, Y. I., Kim, Y. T., Lee, C. L. and Han, I. K. 2000. Carcass and Pork Quality Characteristics by Sex and Marketing Day. J. Anim. Sci. \& Technol. 42(6):933-940.

5. Choi, Y. S. 2004. Studies on the pork quality of Korean native black pigs and its improvement through dietary manipulation. Ph. D. thesis, Kangwon National Univ., Chuncheon, Korea. pp. 1-169.

6. Choi, Y. S., Park, B. Y., Lee, J. M. and Lee. S. K. 2005. Comparison of Carcass and Meat Quality Characteristics between Korean Native Black Pigs and Commercial Crossbred Pigs. Korean J. Food Sci. Ani. Resour. 25:322-327.

7. Hah, K. H., Jin, S. K., Kim, I. S., Song, Y. M., Lee, J. R. and Chung, K. Y. 2005. Pork Quality Characteristics by Different Backfat Thickness. Korean J. Food Sci. Ani. Resour. 25:391-396.

8. Honikel, K. O. 1987. Wasserbindungsvermogen von fleisch. Fleischwirtsch. 67: 418.

9. Hovenier, R., Kanis, E., Brascamp, E. W. and Knap, P. W. 1994. Including meat quality in pig breeding program, Proc. 5th WCGALP 19:465.

10. Jin, S. K., Kim, I. S., Hur, S. J., Kim, S. J. and Jeong, K. J. 2004. The Influence of Pig Breeds on Qualities of Loin. J. Anim. Sci. \& Technol. 48:747-758.

11. Jin, S. K., Kim, I. S., Song, Y. M., Hur, S. J., Hah, K. H., Kim, H. Y., Lyou, H. J., Ha, J. H. and Kim, B. W. 2004. Physic-Chemical Characteristics of Crossbred Pigs with Carcass Grade. Korean J. Food Sci. Anim. Resour. 24:246-252.

12. Joo, S. T., Kauffman, R. G., Kim, B. C. and Park, G. B. 1999. The relationship of sarcoplasmic and myofibrillae protein solubility to colour and water-holding capacity in porcine longissimus muscle. Meat Sci. 52:291-297.

13. Kim, J. H., Park, B. Y., Yoo, Y. M., Cho, S. H., Hwang, I. H., Seong, P. N., Hah, K. H. and Lee, J. M. 2006. Characteristics of Carcass and Meat Quality for Landrace, Yorkshire, Duroc and their Crossbred. Korean J. Anim. Sci. \& Technol. 48(1):101-106.

14. Larzul, C., Lefaucheur, L., Ecolan, P., Gogue, J., Talmant, 
A., Sellier, P., Le Roy, P. and Monin, G. 1997. Phenotypic and genetic parameters for longissimus muscle fiber characteristics in relation to growth, carcass, and meat quality traits in Large White pigs. J. Anim. Sci. $75: 3126$.

15. Lee, J. G. and Joo, S. T. 1999. Effects of Slaughter Weight on Backfat Thickness, Intramuscular Fat and Physical Properties of Pork Loin from Barrow. Korean J. Anim. Sci. 41(2):207-214.

16. Lee. M. S., Lee, Y. I., Lee, S., Kim, S. H., Jung, Y. C., Koh, K. C., Hong, K. C. and Kim, B. C. 1996. Carcass Traits and Pork Quality for Purebred and Crossbred Pigs in Korea. Korean J. Anim. Sci. 38(5):527-535.

17. Park, K. K., Park, H. Y., Jung, Y. C., Lee, E. S., Yang, S. Y., Im, B. S. and Kim, C. J. 2005. Effects of Fermented Food Waste Feeds on Pork Carcass and Meat Quality Properties. Korean J. Food Sci. Technol. 37(1): 38-43.

18. Park. M. J., Ha, D. M., Shin, H. W., Lee, S. H., Kim, W. K., Ha, S. H., Yang, H. S., Jeong, J. Y., Joo, S. T. and Lee, C. Y. 2007. Growth Efficiency, Carcass Quality
Characteristics and Profitability of 'High'-Market Weight Pigs. Korean J. Anim. Sci. \& Technol. 49(4):459-470.

19. Wood, J, D., Enser, M. and Moncrieff, C. B. 1988. Effects of carcass fatness and sex on the composition and quality of pig meat. proc. 34th Inter. Cong. Meat Sci. Techn., Brisbane, Australia, 562.

20. Zhu, L. G. and Brewer, M. S. 1998. Discoloration of fresh pork as related to muscle and display conditions. J. Food Sci. 63:763-767.

21. SAS. 1997. SAS User's Guide : Statistical Analysis System, Cary. NC.

22. 농림부. 2007. 축산물등급판정세부기준. 돼지도체규격등 급과 육질등급판정기준. pp. 15-16.

23. 농림수산식품부. 2008. 주요 축산물 소비량. pp. 104-105.

24. 송영민, 진상근, 이성대, 하경희, 정맹화. 2002. 돈방구조 와 발효사료 급여가 비육돈의 육질에 미치는 영향. 한국 국제농업개발학회지 14(3):169-175.

25. 원광식. 1997. 소·돼지 도체수율 및 육질특성. 농촌진흥 청 축산기술연구소. pp. 11-25.

(접수일자 : 2009. 1. 13. / 수정일자: 2009. 2. 12. /

채택일자 : 2009. 2. 18.) 